\title{
Conditions of vulnerability to the inadequate treatment of bronchiolitis
}

1. Mestre em Ciências pela Faculdade de Medicina da Universidade de São Paulo, São Paulo, SP, Brasil. 2. Médica do Hospital do Servidor Público Estadual de São Paulo (IAMSPE), São Paulo, SP, Brasil. 3. Professora associada do Departamento de Pediatria da Faculdade de Medicina da Universidade de São Paulo, São Paulo, SP, Brasil. 4. Mestre e Doutora em Ciências pela FMUSP, docente do Departamento de Pediatria da FMUSP, São Paulo, SP, Brasil.

\section{SUMMARY}

OBJECTIVE: To analyze clinical and demographic variables possibly associated with the prescriptions of non-recommended but routinely used therapies for infants with acute viral bronchiolitis.

METHODS: A cross-sectional study included hospitalized infants with bronchiolitis caused by the respiratory syncytial virus. Those with other associated infections and/or morbidities were excluded. The data were collected from medical records.

RESULTS: Among 120 cases, 90\% used inhaled beta-agonists, $72.5 \%$ corticosteroids, 40\% antibiotics, and 66.7\% inhaled hypertonic saline solution. The use of bronchodilators did not present an independent association with another variable. More frequent use of corticosteroids was associated with low oximetry, longer hospitalization time, and age $>3$ months. Antibiotic therapy was associated with the presence of fever, longer hospitalization, and age $>3$ months. Inhaled hypertonic saline solution was associated with longer hospitalization time.

CONCLUSIONS: Non-recommended prescriptions were frequent. Corticosteroid and antibiotic therapy were associated with signs of severity, as expected, but interestingly, they were more frequently used in infants above $3 \mathrm{~m}$, which suggested less safety in the diagnosis of viral bronchiolitis in these patients. The use of bronchodilators was even more worrying since they were indiscriminately used, without association with another variable related to the severity or characteristics of the host. The use of the inhaled hypertonic solution, although not associated with severity, seems to have implied a longer hospitalization time. The identification of these conditions of greater vulnerability to the prescription of inappropriate therapies contributes to the implantation of protocols for the bronchiolitis treatment, for continuing education and for analysis of the effectiveness of the strategies employed.

DESCRIPTORS: Respiratory syncytial viruses. Bronchiolitis. Drug therapy.

\section{INTRODUCTION}

Acute viral bronchiolitis (AVB) has been known for over 50 years as a viral infection that affects infants and whose main etiologic agent is the respiratory syncytial virus (RSV). AVB is considered the main cause of hospitalization among infants ${ }^{12}$. It affects about 60 million infants yearly worldwide and causes over 3.4 million hospitalizations and about 160,000 deaths, but various aspects of its etiopathogenesis remain unknown, and there have been few therapeutic advances $^{1-3}$.

Currently, the recommended treatment for bronchiolitis consists of implementing patient support measures through oxygen and hydration ${ }^{4-6}$. However, its clinical similarity with an asthma crisis leads to

DATE OF SUBMISSION: 12-Jun-2019

DATE OF ACCEPTANCE: 29-Jun-2019

CORRESPONDING AUTHOR: Sandra Vieira

Faculdade de Medicina da Universidade de São Paulo, Departamento de Pediatria

Av. Dr. Eneas de Carvalho Aguiar, 647, São Paulo, SP, Brasil - CEP 05403-000

Tel: +5511999622088

E-mail: sandra.vieira@fm.usp.br, sandra@hu.usp.br 
frequent prescriptions of bronchodilators, corticosteroids, and antibiotics worldwide. Seeking to improve the management of these patients and avoid inappropriate therapies, national and international guidelines were created based on scientific evidence, which do not recommend the routine use of these medications. Some countries have instituted the use of guidelines and follow up under continuing education of the health professionals responsible for such therapies and obtained an improvement in the adequacy of AVB treatment ${ }^{7-10}$.

On the other hand, different patterns of AVB have been described, including phenotypes and characteristics such as gene expression profile and transcriptomes associated with the etiologic agent ${ }^{11.12}$.

In the present study, we investigated the associations between demographic and clinical variables and the therapies used despite not being recommended for routine treatment. The identification of conditions under greater vulnerability to the prescription of inadequate therapy seeks to contribute to the implementation of protocols for the treatment of AVB, to continuing education, and further comparisons and analysis of the effectiveness of the strategies employed.

\section{METHODS}

A descriptive and analytic cross-sectional study was carried out on a convenience sample of infants aged between 0 and 2 years treated in the Pediatrics Emergency Service of the Hospital do Servidor Público Estadual of São Paulo (IAMSPE) and subsequently admitted to this service, between November 2012 and October 2014, and who underwent etiological investigation for the respiratory syncytial virus during the first episode of wheezing. This hospital provides high-complexity assistance for 1.3 million state employees and their dependants.

We included all infants in their first episode of wheezing (defined by the presence of wheezing during pulmonary auscultation) and submitted nasopharyngeal aspirate collection for RSV investigation. We excluded patients diagnosed with or suspected of other associated infections at admission or during hospitalization, as well as those with other comorbidities. The data were collected from medical records and via telephone by means of standardized protocols. We analyzed the sociodemographic characteristics, signs, and symptoms on admission, medications prescribed during hospitalization, the need for mechanical ventilation and supplemental oxygen. The medication prescriptions were evaluated according to the age of the patient, the hospitalization day of the week, presence of fever (on admission), oximetry value (on admission), hospitalization in the intensive care unit (ICU), and length of hospitalization. In accordance with the service protocol during the period studied, oxygen therapy was indicated for maintaining the levels of oxygen saturation above $95 \%$, according to pulse oximetry. The criteria for hospitalization were signs of tachydyspnea and/or maintenance of oxygen saturation below $95 \%$ after a reassessment of the initial service in the Emergency Room.

The collection of nasopharyngeal secretion was performed by the nursing staff routinely in all infants with a first episode of wheezing, and the samples were immediately submitted to the hospital laboratory. The rapid immunochromatographic test used was the RSV BinaxNOW ${ }^{\circledR}$ by Alere, which can identify subgroups $A$ and $B$ of RSV, with results available in 15 minutes.

The parents or legal guardians of the children were informed about the study and signed the informed consent form. This study was approved by the Research Ethics Committee of the Faculty of Medicine of USP (40796314.4.0000.0065).

\section{Statistical analysis}

We used the chi-square test for categorical variables and the Mann-Whitney test for continuous ones. The associations (variables/outcomes) were studied by univariate and multivariate logistic regression analysis. The variables whose associations were significant in the univariate analysis were included in the multivariate analysis. P values $<0.05$ was considered statistically significant. We used Stata $10.0^{\circledR}$.

\section{RESULTS}

A total of 321 tests were conducted to detect RSV in the pediatrics emergency service of IAMSPE in infants with a first episode of wheezing. There were 192 samples with negative results, which were not selected. Among the 129 (40.2\%) samples with positive results for RSV, seven were excluded from the study because the patients had comorbidities: pneumonia (four cases), heart disease (one case), and two patients were excluded because they were infected with RSV during their hospitalization due to another pathology. Two medical charts were not located. There was, therefore, a total of $1.5 \%$ losses and $5.4 \%$ exclusions. 
The number of cases of bronchiolitis due to RSV was higher in the months of March, April, May, and

TABLE 1. SOCIODEMOGRAPHIC CHARACTERISTICS OF INFANTS WITH RESPIRATORY SYNCYTIAL VIRUS INFECTION

\begin{tabular}{|c|c|}
\hline SEX & $N(\%)$ \\
\hline Female & $62(51.6 \%)$ \\
\hline Male & $58(48.3 \%)$ \\
\hline COLOR $^{*}$ & $N(\%)$ \\
\hline White & 54 (58.1\%) \\
\hline Brown & $21(22.6 \%)$ \\
\hline Black & $18(19.3 \%)$ \\
\hline Yellow & $0(0 \%)$ \\
\hline Indigenous & $0(0 \%)$ \\
\hline \multicolumn{2}{|l|}{ TYPE OF DELIVERY } \\
\hline C-section & $72(62.6 \%)$ \\
\hline Vaginal & $43(37.4 \%)$ \\
\hline Prematurity (GA<37 weeks) & $N(\%)$ \\
\hline Yes & $15(13.1 \%)$ \\
\hline No & $100(86.9 \%)$ \\
\hline BIRTH WEIGHT & $N(\%)$ \\
\hline$<1,500 \mathrm{~g}$ & $4(3.5 \%)$ \\
\hline $1,500-2,000 \mathrm{~g}$ & $6(5.2 \%)$ \\
\hline $2,001-2,500 \mathrm{~g}$ & $6(5.2 \%)$ \\
\hline $2,501-3,000 \mathrm{~g}$ & $21(18.3 \%)$ \\
\hline$<3,000 \mathrm{~g}$ & $78(67.8 \%)$ \\
\hline BREASTFEEDING & $N(\%)$ \\
\hline Yes & $83(84.7 \%)$ \\
\hline No & $15(15.3 \%)$ \\
\hline BREASTFEEDING DURATION (months) & $M D(D P)$ \\
\hline Exclusive & $3.7(4.12)$ \\
\hline Mixed & $5.9(8.01)$ \\
\hline SIBLINGS & $N(\%)$ \\
\hline Yes & $73(78.5 \%)$ \\
\hline No & $20(21.5 \%)$ \\
\hline NUMBER OF SIBLINGS & $N(\%)$ \\
\hline 1 Sibling & $42(58.3 \%)$ \\
\hline 2 Siblings & $23(31.9 \%)$ \\
\hline 3 Siblings & $3(4.2 \%)$ \\
\hline 4 Siblings & $2(2.8 \%)$ \\
\hline$>4$ Siblings & $2(2.8 \%)$ \\
\hline NURSERY & $N(\%)$ \\
\hline Yes & $69(76.7 \%)$ \\
\hline No & $21(23.3 \%)$ \\
\hline SMOKING DURING PREGNANCY & $N(\%)$ \\
\hline Yes & $05(5.6 \%)$ \\
\hline No & $85(94.4 \%)$ \\
\hline SMOKERS IN THE HOUSEHOLD & $N(\%)$ \\
\hline Yes & $11(11.9 \%)$ \\
\hline \multirow[t]{2}{*}{ AGE AT ADMISSION (months) } & MDI (IQ) \\
\hline & $6.8(2.7-12.4)$ \\
\hline DAY OF ADMISSION & $N(\%)$ \\
\hline Weekday & $102(85 \%)$ \\
\hline Weekend & $18(15 \%)$ \\
\hline
\end{tabular}

June of the years 2013 and 2014. Their sociodemographic characteristics are presented in Table 1 . The most frequent signs and symptoms at the time of admission were: cough (96.7\%), oxygen saturation of $<95 \%$ (76.5\%), respiratory discomfort (67.2\%), wheezing (61.5\%), and fever (35\%). The therapeutic interventions are presented in Table 2. Admission to the ICU was necessary in $15 \%$ of cases, and $7.5 \%$ were submitted to invasive ventilation.

The univariate analyses of the associations between the therapy used and the variables "age", "presence of fever", and "pulse oximetry", with the variables "hospitalization during weekends," "hospitalization in Intensive Care Unit" and "hospitalization length" and the multivariate analyses of the therapy associations used with an adjustment for variables that were significant in the univariate analyses are presented in Table 3.

\section{DISCUSSION}

The study examined the associations between the approaches used in infants with bronchiolitis caused by RSV and clinical and demographic factors.

TABLE 2. THERAPY INTERVENTIONS PRESCRIBED TO INFANTS ADMITTED WITH RESPIRATORY SYNCYTIAL VIRUS INFECTION

\begin{tabular}{l|l}
\hline THERAPY & $\mathrm{N}(\%)$ \\
\hline Admission to ICU & $18(15 \%)$ \\
\hline Invasive ventilation & $09(7.5 \%)$ \\
\hline Corticosteroids & $87(72.5 \%)$ \\
\hline Intravenous fluids & $84(70 \%)$ \\
\hline Inhaled epinephrine & $12(10 \%)$ \\
\hline Inhaled hypertonic saline solution & $80(66.7 \%)$ \\
\hline Inhaled bronchodilator & $108(90 \%)$ \\
\hline Oxygen therapy & $97(80.8 \%)$ \\
\hline Antibiotics & $48(40 \%)$ \\
\hline \multicolumn{1}{c}{ Clarithromycin } & $16(33.3 \%)$ \\
\hline Penicillin & $6(12.5 \%)$ \\
\hline Azithromycin & $3(6.2 \%)$ \\
\hline Ampicillin & $2(4.2 \%)$ \\
\hline Others & $2(4.2 \%)$ \\
\hline Invasive ventilation & MD (DP) \\
\hline Corticosteroids & $5.7(3.38)$ \\
\hline Intravenous fluids & $4.7(3.25)$ \\
\hline Inhaled epinephrine & $3.2(2.1)$ \\
\hline Inhaled hypertonic saline solution & $1.9(1.3)$ \\
\hline Inhaled bronchodilator & $4.4(2.9)$ \\
\hline Oxygen therapy & $5.2(3.8)$ \\
\hline Antibiotics & $4.7(2.9)$ \\
\hline & $3.4(2.97)$ \\
\hline
\end{tabular}


TABLE 3. UNIVARIATE AND MULTIVARIATE ANALYSES OF THE ASSOCIATIONS BETWEEN THE THERAPIES USED AND DEMOGRAPHIC AND CLINICAL VARIABLES

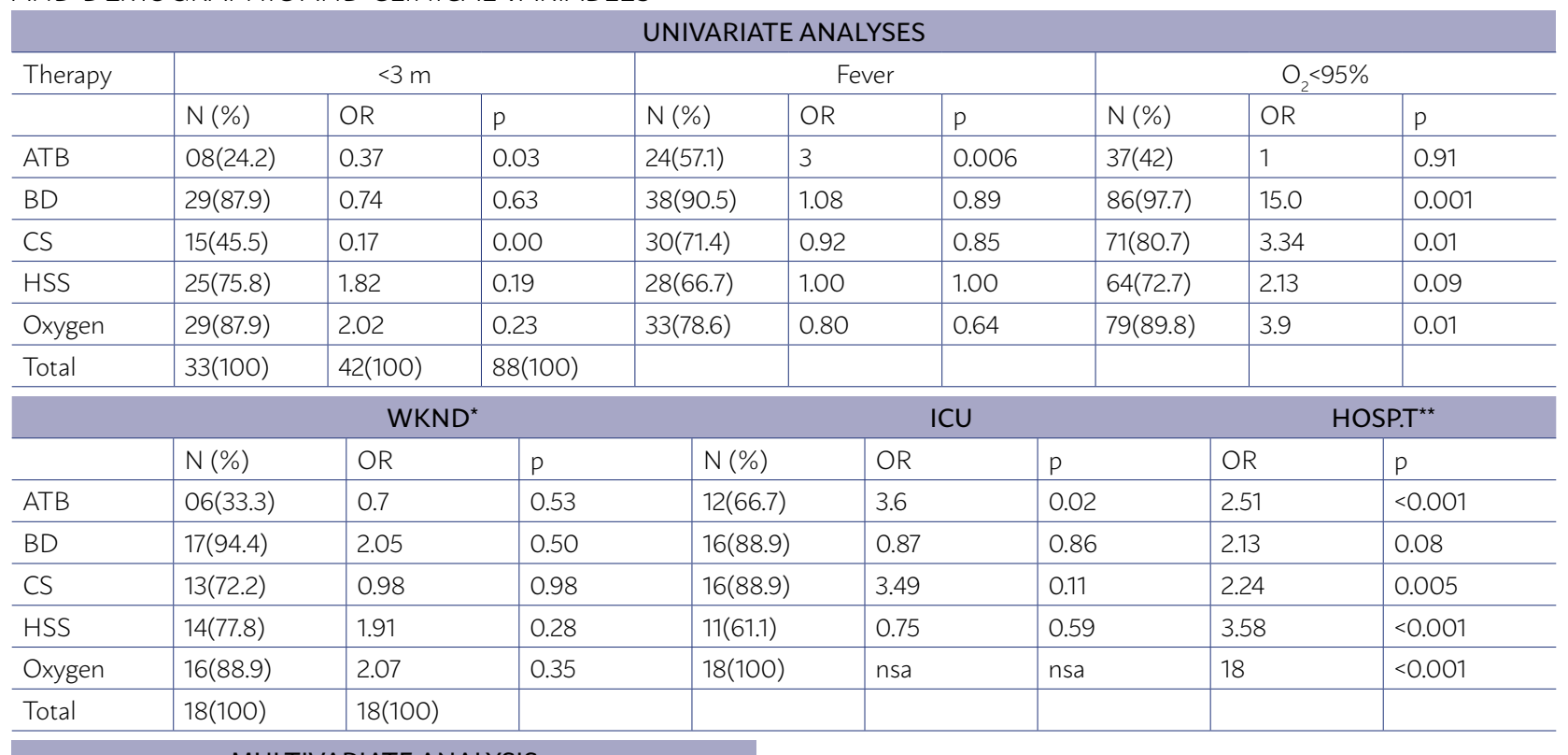

\begin{tabular}{|c|c|c|}
\hline \multicolumn{3}{|c|}{ MULTIVARIATE ANALYSIS } \\
\hline USE OF ANTIBIOTICS & & \\
\hline & OR & $p$ \\
\hline Fever & 3.0 & 0.013 \\
\hline Age $<3 \mathrm{~m}$ & 0.21 & 0.007 \\
\hline Length of hospital stay & 2.53 & 0.003 \\
\hline Admission to ICU & 3.44 & 0.07 \\
\hline \multicolumn{3}{|c|}{ USE OF CORTICOSTEROIDS } \\
\hline & OR & $p$ \\
\hline Sat $\mathrm{O}_{2}<95 \%$ & 3.17 & 0.037 \\
\hline Length of hospital stay & 2.98 & 0.004 \\
\hline Age $<3 \mathrm{~m}$ & 0.67 & $<0.001$ \\
\hline \multicolumn{3}{|c|}{$\begin{array}{l}\text { USE OF INHALED HYPERTONIC SA- } \\
\text { LINE SOLUTION }\end{array}$} \\
\hline & OR & $p$ \\
\hline Length of hospital stay & 3.07 & $<0.001$ \\
\hline Sat $\mathrm{O}_{2}<95 \%$ & 1.89 & 0.201 \\
\hline \multicolumn{3}{|c|}{ USE OF BRONCHODILATORS } \\
\hline & OR & $p$ \\
\hline Age $<3 \mathrm{~m}$ & 0.734 & 0.634 \\
\hline \multicolumn{3}{|l|}{ OXYGEN THERAPY } \\
\hline & OR & $p$ \\
\hline Sat $\mathrm{O}_{2}<95 \%$ & 3.324 & 0.056 \\
\hline Length of hospital stay & 12.9 & $<0.001$ \\
\hline
\end{tabular}

ATB = antibiotic therapy; $\mathrm{BD}=$ inhaled bronchodilators; $\mathrm{CS}=$ corticosteroids; $\mathrm{HSS}=$ inhaled hypertonic saline solution. ${ }^{*} \mathrm{WKND}=$ weekends, ICU $=$ Intensive Care Unit ${ }^{\star *}$ HOSP.T = duration of hospitalization. Time analyzed in three categories: $<3$ days, between 4 and 7 days, and $>7$ days. The OR refers to the chance of going from one category to the next. Logistic regression test

The prescriptions rates of bronchodilators, corticosteroids, and antibiotics were high, contrary to the recommendations of the main guidelines in force during the time of hospitalization of these patients ${ }^{5.13}$. The analyses of the conditions associated with such practices emphasize the value placed on clinical severity. One aspect not previously explored stands out: a younger age proved to be a protective factor, which suggests that the infants older than 3 months are more vulnerable to inappropriate therapies and, therefore, guidelines for health professionals should highlight recommendations for this age group.

The odds of corticosteroids prescription for young infants was approximately $50 \%$ lower than for those older than 3 months. It is interesting to note that we only included cases with confirmed etiologic identification of RSV, and, despite that, the use of corticosteroids was high. These results suggest that the RSV etiology in younger infants has been less associated with recurrent wheezing or asthma. It is possible that the inflammatory process involved in the pathogenesis of AVB and the clinical presentation similarity with an asthma crisis are the reason for this use, despite the contrary recommendations of the guidelines ${ }^{4-6,13}$. The prescription of corticosteroids was also independently associated with lower levels of oxygen saturation, which suggests the influence of the severity of the respiratory condition. It is worth noting that the level adopted for the institution of oxygen therapy was an oxygen saturation below $95 \%$, which may have contributed to the assessment of severity. However, the excessive and erroneous use of corticotherapy in AVB is described worldwide, despite not being recommended by national and international consensus ${ }^{4-6}$. Several studies have failed to show the benefits of its systemic or inhaled use in reducing hospitalization time or rates ${ }^{14}$.

Age less than 3 months was also a protector for 
the use of antibiotics. Using the same reasoning previously applied to the association between corticosteroids and age, it is possible that the diagnosis of associated bacterial pneumonia was suspected more often in older children, while AVB as a single diagnosis was more often associated with young infants. The use of antibiotics is banned in all guidelines, except for severe cases with the need for mechanical ventilation or concomitant bacterial infection (confirmed or suspected $)^{4-6}$. Against recommendations, antibiotics were administered to $40 \%$ of patients with RSV infection. The presence of fever at admission was a factor that favored the prescription of this drug; however, studies indicate that the low probability of fever being associated with a severe bacterial coinfection in BVA does not justify the introduction of an antimicrobial agent ${ }^{15}$.

The use of inhaled bronchodilators was high. Pulse oximetry below 95\% was associated with the prescription of this drug; however, this association was not independent after adjustment for confounding factors, which suggests that the indication was indiscriminate, regardless of other variables. The 2016 guidelines by the American Academy of Pediatrics allowed resorting to the use of this drug as a therapeutic trial and maintaining it in the event of a satisfactory clinical response ${ }^{13}$. A multicenter study that included 28 studies on beta-agonists and 1,912 patients showed that the drug does not reduce the hospitalization rate or time ${ }^{16}$. Current guidelines do not recommend the use of beta-agonists in children with bronchiolitis ${ }^{4.6}$.

The inhaled epinephrine is also not recommended by the guidelines for the treatment of $\mathrm{AVB}^{5.13}$. Epinephrine was administered to $10 \%$ of patients for post-extubation laryngitis. A Cochrane systematic review showed no reduction in the time of hospitalization for bronchiolitis with the use of epinephrine or any other benefit ${ }^{17}$.

The inhalation of $3 \%$ hypertonic saline was prescribed for most of the patients in the study. After adjustments for confounding factors, the prescription of this medication was not associated with low levels of oxygen saturation. As mentioned above, it is possible that the 95\% threshold for saturation led to increased use of the hypertonic saline solution, due to the clinical severity. Another interesting aspect was the independent association of the use of the inhaled hypertonic saline solution, and longer hospitalization time, i.e., the therapy may have led to prolonged hospitalization, possibly due to a delay in its suspension. At the time, National Guideline advocated for the use of the hypertonic saline solution in association with bronchodilators in order to avoid reflex bronchospasm ${ }^{5}$. What supported this indication was the possibility of promoting an osmotic flow towards the mucus present in the airways and improving cell rhythm ${ }^{18}$. Although the inhaled hypertonic solution can promote benefits in patients with cystic fibrosis, the same thing is not observed in $\mathrm{AVB}^{18}$. The current 2017 guidelines by the Brazilian Society of Pediatrics do not recommend the routine use of inhaled hypertonic saline solution ${ }^{5}$. Other guidelines, such as the British, also do not recommend it ${ }^{6}$.

The characteristics of the sample studied point to the possibility of applying these results in clinical practice. The identification of RSV present in respiratory secretions in $40.2 \%$ of AVB cases was compatible with data from the literature since the study included infants hospitalized for a period of two years, even outside of the seasonality period of RSV, which decreases the final positivity of the etiological investigation for this agent ${ }^{19.20}$. The sociodemographic characteristics and breastfeeding rates found are compatible with the population of infants born at term in the city of São Paulo ${ }^{5.21}$. The clinical presentation with a predominance of cough, hypoxemia, respiratory distress, and wheezing is characteristic of AVB caused by RSV with moderate to high severity. The need for hospitalization in the Intensive Care Unit and mechanical ventilation are in line with other Brazilian studies that reported rates of ICU hospitalization between $6 \%$ and $17 \%$, with the need for invasive ventilation between $2.8 \%$ and $7 \%$ 22.23.

The application of the guidelines, with the training of the medical and nursing staff, seems to be the most effective measure to reduce inappropriate therapies. A multicenter study carried out in 21 hospitals showed a decrease of $68 \%$ in the prescription of corticosteroids, $29 \%$ in the use of bronchodilators, and $44 \%$ in the number of radiographs after interactive monthly seminars ${ }^{11}$. Another aspect that could contribute to the conduct is the availability of tests to identify the etiology of AVB. Although the guidelines do not state the need for etiologic confirmation of AVB in order to implement the recommended therapies, there is still controversy since some studies show an impact on the etiologic diagnosis ${ }^{22.24}$. A study conducted at the University Hospital of the Universidade de São 
Paulo, in São Paulo, observed that, after the implementation of investigation for respiratory viruses, there was a reduction by $32.2 \%$ in the prescription of antibiotics for patients who tested positive a virus and $9.2 \%$ for those with negative results. This reduction was not observed regarding the use of corticosteroids and bronchodilators ${ }^{22}$.

It is possible that a set of measures that include the identification of the viral agent in addition to treatment recommendations based on national and international guidelines implemented with continuing education support programs to the entire staff involved in patient care can promote proper patient support, minimizing unnecessary drug prescriptions.

The identification of demographic and clinical conditions associated with the increased use of inappropriate therapies can contribute to continuing education and the greater protection of patients more vulnerable to iatrogenesis.

\section{CONCLUSIONS}

Infants with more severe clinical conditions, especially those over the age of 3 months, were more vulnerable to the inadvertent use of corticosteroids and antibiotics, possibly by greater insecurity in the diagnosis of viral bronchiolitis, although the etiology by RSV was identified. Even more worrying was the indiscriminate use of bronchodilators, which was not associated with any variable. It is also noteworthy that inhaled hypertonic solution was indicated regardless of the severity of the case and seems to have caused a greater time of hospitalization.

\section{Contribution of the authors}

Kattia C. Naves - Project design, data collection, analysis and interpretation of the results, drafting of the manuscript. Sandra E. Vieira - Conception of the study, project design, analysis and interpretation of the results, production and revision of the manuscript.

\section{RESUMO}

OBJETIVOS: Analisar variáveis clínicas e demográficas possivelmente associadas às prescrições de terapêuticas não recomendadas, porém rotineiramente utilizadas, para lactentes com bronquiolite viral aguda.

MÉTODOS: Estudo transversal incluiu lactentes hospitalizados com bronquiolite por vírus sincicial respiratório. Excluídos aqueles com outras infecções e/ou morbidades. Dados coletados de prontuários.

RESULTADOS: Analisados 120 casos, para os quais foram prescritos: beta-agonistas inalatórios a 90\%; corticosteroides a 72,5\%, antibióticos a 40\% e solução salina hipertônica inalatória a $66,7 \%$. O uso de broncodilatadores não apresentou associação independente com outra variável. Maior uso de corticosteroide associou-se à baixa oximetria, maior tempo de internação e idade >3 meses. Antibioticoterapia associou-se à presença de febre, maior tempo de internação e idade >3 meses. Solução salina hipertônica inalatória associou-se a maior tempo de internação.

CONCLUSÕES: A frequência das prescrições não recomendadas foi elevada. Corticosteroide e antibioticoterapia foram associados a sinais de gravidade, como esperado, porém, interessantemente, foram mais utilizados nos lactentes com idade acima de 3 meses, o que sugeriu menor segurança no diagnóstico de bronquiolite viral nesses pacientes. O uso de broncodilatadores foi ainda mais preocupante, uma vez que foram indiscriminadamente utilizados, sem associação com outra variável, seja relacionada à gravidade, seja a características do hospedeiro. O uso de solução hipertônica inalatória, apesar de não associado à gravidade, parece ter implicado maior tempo de internação. A identificação dessas condições de maior vulnerabilidade à prescrição de terapêuticas inadequadas contribui para a implantação de protocolos para o tratamento da BVA, para educação continuada e para posteriores comparações e análises de eficácia das estratégias empregadas.

PALAVRAS-CHAVE: Vírus sinciciais respiratórios. Bronquiolite. Tratamento farmacológico.

\section{REFERENCES}

1. Nair H, Nokes DJ, Gessner BD, Dherani M, Madhi SA, Singleton RJ, et al. Global burden of acute lower respiratory infections due to respiratory syncytial virus in young children: a systematic review and meta-analysis. Lancet. 2010;375(9725):1545-55

2. Karampatsas K, Kong J, Cohen J. Bronchiolitis: an update on management and prophylaxis. Br J Hosp Med (Lond). 2019;80(5):278-84.

3. Miller EK, Gebretsadik T, Carroll KN, Dupont WD, Mohamed YA, Morin $\mathrm{LL}$, et al. Viral etiologies of infant bronchiolitis, croup and upper respiratory illness during 4 consecutive years. Pediatr Infect Dis |. 2013;32(9):950-5.

4. Ralston SL, Lieberthal AS, Meissner HC, Alverson BK, Baley JE, Gadomski AM, et al; American Academy of Pediatrics. Clinical practice guideline: the diagnosis, management, and prevention of bronchiolitis. Pediatrics. 2014;134(5):e1474-502.
5. Sociedade Brasileira de Pediatria. Diretrizes para o manejo da infecção causada pelo vírus sincicial respiratório. [cited 2019 May 3]. Available from: https://www.sbp.com.br/fileadmin/user_upload/Diretrizes_manejo_infeccao_causada_VSR2017.pdf

6. National Institute for Health and Care Excellence. Bronchiolitis in children: diagnosis and management. 2015. [cited 2019 May 3]. Available from: https://www.nice.org.uk/guidance/ng9

7. Breakell R, Thorndyke B, Clennett |, Harkensee C. Reducing unnecessary chest $X$-rays, antibiotics and bronchodilators through implementation of the NICE bronchiolitis guideline. Eur | Pediatr. 2018;177(1):47-51.

8. Barr R, Carande EJ, Pollard AJ, Drysdale SB. Change in viral bronchiolitis management in hospitals in the UK after the publication of NICE guideline. J Clin Virol. 2018;105:84-87. 
9. Ralston S, Garber M, Narang S, Shen M, Pate B, Pope J, et al. Decreasing unnecessary utilization in acute bronchiolitis care: results from the value in inpatient pediatrics network. J Hosp Med. 2013;8(1):25-30.

10. Ralston SL, Garber MD, Rice-Conboy E, Mussman GM, Shadman KA, Walley SC, et al; Value in inpatient pediatrics network quality collaborative for improving hospital compliance with AAP Bronchiolitis Guideline (BQIP). A multicenter collaborative to reduce unnecessary care in inpatient bronchiolitis. Pediatrics. 2016;137(1).

11. Rodríguez-Martínez CE, Castro-Rodriguez JA, Nino G, Midulla F. The impact of viral bronchiolitis phenotyping: is it time to consider phenotype-specific responses to individualize pharmacological management? Paediatr Respir Rev. 2019; pii: S1526-0542(18)30163-5.

12. Vieira SE, Bando SY, Paulis M, Oliveira DBL, Thomazelli LM, Durigon EL, et al. Distinct transcriptional modules in the peripheral blood mononuclear cells response to human respiratory syncytial virus or to human rhinovirus in hospitalized infants with bronchiolitis. PLoS One. 2019;14(3):e0213501.

13. American Academy of Pediatrics Subcommittee on Diagnosis and Management of Bronchiolitis. Diagnosis and management of bronchiolitis. Pediatrics. 2006;118(4):1774-93.

14. Fernandes RM, Bialy LM, Vandermeer B, Tjosvold L, Plint AC, Patel H, et al Glucocorticoids for acute viral bronchiolitis in infants and young children. Cochrane Database Syst Rev. 2013(6):CD004878.

15. Levine DA, Platt SL, Dayan PS, Macias CG, Zorc II, KriefW, et al; Multicenter RSV-SBI Study Group of the Pediatric Emergency Medicine Collaborative Research Committee of the American Academy of Pediatrics. Risk of serious bacterial infection in young febrile infants with respiratory syncytial virus infections. Pediatrics. 2004;113(6):1728-34.
16. Gadomski AM, Brower M. Bronchodilators for bronchiolitis. Cochrane Database Syst Rev. 2010(12):CD001266

17. Hartling L, Bialy LM, Vandermeer B, Tjosvold L, Johnson DW, Plint AC, et al. Epinephrine for bronchiolitis. Cochrane Database Syst Rev. 2011(6):CD003123.

18. Mandelberg A, Amirav I. Hypertonic saline or high volume normal saline for viral bronchiolitis: mechanisms and rationale. Pediatr Pulmonol. 2010;45(1):36-40.

19. Papenburg J, Buckeridge DL, De Serres G, Boivin G. Host and viral factors affecting clinical performance of a rapid diagnostic test for respiratory syncytial virus in hospitalized children. | Pediatr. 2013;163(3):911-3.

20. Vieira SE, Stewien KE, Queiroz DA, Durigon EL, Török T], Anderson Ll, et al. Clinical patterns and seasonal trends in respiratory syncytial virus hospitalizations in São Paulo, Brasil. Rev Inst Med Trop Sao Paulo. 2001;43(3):125-31.

21. Sena MC, Silva EF, Pereira MG. Prevalence of breastfeeding in Brazilian capital cities. Rev Assoc Med Bras. 2007;53(6):520-4.

22. Ferronato ÂE, Gilio AE, Ferraro AA, Paulis M, Vieira SE. Etiological diagnosis reduces the use of antibiotics in infants with bronchiolitis. Clinics (Sao Paulo). 2012;67(9):1001-6.

23. DallOnder ILC, Sechi FL, Sander MB, Eckert GU. Profile of patients admitted in an intensive care unit for acute viral bronchiolitis in a South Brazilian children's hospital. Rev AMRIGS. 2014;58(2):130-4.

24. Doan Q, Enarson P, Kissoon N, Klassen TP, Johnson DW. Rapid viral diagnosis for acute febrile respiratory illness in children in the Emergency Department. Cochrane Database Syst Rev. 2014(9):CD006452. 